\title{
Desain Pengembangan Pariwisata dan Ekonomi Masyarakat di Pantai Botutonuo
}

\author{
Febiola Kusuma ${ }^{1)}$, Muhammad Amir Arham ${ }^{2)}$, Sri Indriyani S. Dai ${ }^{3)}$ \\ 1)Mahasiswa Fakultas Ekonomi, Universitas Negeri Gorontalo \\ 2),3)Dosen Fakultas Ekonomi, Universitas Negeri Gorontalo \\ febiolakusuma10@gmail.com
}

\begin{abstract}
The research aims to find out the Design of Development of Tourism and community Economic in Botutonuo Beach, Bone Bolango District by distributing questionnaire to respondents. The data are collected from result of observation, questionnaire, and documentation. The data analysis user SWOT analysis to discover the IFAS and EFAS, SWOT matrix, and strategy diagram in the SWOT. The research finding shows that the position of development strategy of tourism and community economic in Botutonuo Beach, Bone Bolango District is currently in quadrant III or Turnaround strategy. The strategy emphasizes the importance of government commitment on focus of regional tourism development which can be performed through (1) implementing sapta pesona (seven ways of enchantment) for Botutonuo Beach as tourist attraction, (2) creating city branding for Botutonuo Beach, (3) conducting capacity building for neighboring community in terms of community-based creative economy and tourism, (4) creatimg tourism master plan and sustainable development, (5) optimizing role of tourism institution in meeting LocallyGenerated Revenue target of the District and improving community economic including in reducing poverty and increasing labor absorption in Botutonuo Village. The development strategy should be encouraged more and directed properly to improve the tourism comparative and competitive advantages in Bone Bolango District.
\end{abstract}

\section{Keyword: Tourism Development, Community Economic}

\section{Pendahuluan}

Pariwisata mempunyai

multiplier effect yang luas, sehingga

mampu meningkatkan pendapatan daerah melalui pajak daerah dan retribusi juga dapat meningkatkan pendapatan perkapita masyarakat. Hal ini dikarenakan semakin meluasnya kegiatan ekonomi oleh masyarakat dan pendatang (wisatawan) bukan hanya di lokasi pariwisata itu saja, tetapi juga kegiatan ekonomi di luar pariwisata (Ni'mah, 2016).

Dari sudut ekonomi bahwa kegiatan pariwisata dapat memberikan sumbangan terhadap penerimaan daerah bersumber dari pajak, retribusi parkir dan karcis atau dapat mendatangkan devisata dari parawisatawan Negara yang 
berkunjung adanya pariwisata juga akan menumbuhkan usaha-usaha ekonomi yang saling merangkai dan menunjang kegiatannya sehingga dapat meningkatkan pendapatan masyarakat. Pengembangan keparawisataan semakin esensial atau penting terlebih untuk perekonomian misalnya dalam hal penyerapan tenaga kerja dan penciptaan lapangan usaha baru yang pada gilirannya akan berimbas pada meningkatnya perekonomian masyarakat itu sendiri.

Pentingnya mengembangkan pariwisata akan berkaitan erat dengan manfaat secara ekonomi bagi masyarakat, maka dari itu pengembangan pariwisata harus memperhatikan kondisi social ekonomi masyarakat di daerah tersebut. Dalam mengembangkan suatu daerah yang fokus pada pariwisata harus memperhatikan berbagai faktor-faktor yang berpengaruh terhadap keberadaan suatu daerah tujuan wisata. Suwantoro (2004) mengemukaan ada 5 unsur pokok yang harus ada di suatu daerah tujuan wisata seperti objek dan daya tarik wisata, prasarana wisata, infrastuktur, serta kondisi dari masyarakat atau linkungan.

Pada tahun 2010, Pemerintah mengembangkan konsep minapolitan artinya kota perikanan dimana konsep pembangunan lebih diarahkan pada pembangunan ekonomi dengan pendekatan wilayah yang dapat dimaknai sebagai sistem pengelolaan kawasan perintegrasi, kualitas, efisien, dan adanya percepatan yang tinggi. Pemerintah saat itu memiliki target untuk menjadi penghasil produk perikanan dan kelautan terbesar pada tahun 2015 namun konsep ini kurang menyentuh pengembangan potensi wisata namun lebih mengoptimalkan pemanfaatan sumber daya kelautan dan perikanan untuk meningkatkan kesejahteraan masyarakat.

Salah satu potensi yang dapat di kembangkan adalah teluk tomini yang berada di tiga provinsi di Pulau Sulawesi yaitu Sulawesi Utara, Gorontalo dan Sulawesi Tengah. Provinsi Gorontalo berada pada provinsi terpanjang bila di bandingkan dengan provinsi lain. Konsep etalase kelautan di teluk tomini dan pengembangan potensi wisata bahari menjadi program yang cukup untuk mendapatkan perhatian bnyak pihak yang termasuk mendapatkan perhatian banyak termasuk pemerintah pusat. Pantai Botutonuo di Kabupaten Bone Bolango sedang mengembangkan memiliki ciri khas objek wisata yang akan menjadi lokomotif ekonomi baru terutama memberikan dampak bagi ekonomi masyarakat dan pertumbuhan ekonomi Kabupaten Bone Bolango.

Fakta menunjukan bahwa potensi pariwisata diwilayah ini belum menjadi faktor pendorong dan mengembangkan perekonomian masyarakat pesisir dan belum mampu mendongkrak perekonomian masyarakat karena belum adanya keberlanjutan kebijakan pembangunan terutama di sector wisata bahari. Masyarakat pesisir masih lebih dominan menggantungkan hidupnya pada ekonomi yang bersumber dari perikanan tangkap dengan tanpa dukungan iklim dan cuaca yang salalu menguntungkan bagi nelayan. Disisi lain sektor pariwisata pantai Botutonuo belum mampu mengoptimalkan pengelolaan potensi wisata bahari yang 
dapat tercermin dari pariwisatawan yang datang berkunjung tidak melakukan eksploitasi perikanan dan kelautan melainkan hanya menikmati keindahan pantai Botutonuo tersebut.

Lemahnya kualitas SDM rumah tangga dan kelembagaan, penyiapan SDM yang terampil di bidang kepariwisataan, pengolahan dan pengembangan desain produk berbahan baku lokal agar produk berdaya saing, penyiapan sarana dan prasarana (infrastruktur), yang akan berdampak pada peningkatan nilai tambah ekonomi masih jauh dari harapan.

Perubahan pola kehidupan masyarakat di Provinsi Gorontalo khususnya di Kabupaten Bone Bolango sudah menunjukan perubahan yang dinamis dan maju dimana kebutuhan akan lokasi wisata mampu menjadi penawar dari tingkat kejenuhan dari berbagai kegiatan pekerjaan oleh masyarakat kota. Peluang ini harus mampu dibaca oleh pemerintah dan masyarakat di kawasan Botutonuo Kabupaten Bone Bolango yang pada hakikatnya kaya akan potensi wisata bahari pantai Botutonuo tersebut. Sehingga penulis tertarik melakukan kajian penelitian tentang Desain Pengembangan Pariwisata Dan Ekonomi Masyarakat Di Pantai Botutonuo Kabupaten Bone Bolango.

\section{Tinjauan Pustaka}

Keterlibatan peran serta masyarakat dalam pengembangan dan pengelolaan pariwisata menjadi salah satu faktor penting, karena masyarakatlah yang memahami dan menguasai wilayahnya (Elfianita, E.
2016). Pariwisata merupakan kegiatan yang dapat dipahami dari banyak pendekatan (Ismayanti, 2010). Dalam Undang-undang RI nomor 10 Tahun 2009 tentang Kepariwisataan dijelaskan bahwa:

1. Wisata adalah kegiatan perjalanan yang dilakukan oleh seseorang atau sekelompok orang dengan mengunjungi tempat tertentu untuk tujuan rekreasi, pengembangan pribadi, atau mempelajari keunikan daya tarik wisata yang dikunjungi, dalam jangka waktu sementara.

2. Wisatawan adalah orang yang melakukan wisata.

3. Pariwisata adalah berbagai macam kegiatan wisata dan didukung berbagai fasilitas serta layanan yang disediakan oleh masyarakat, pengusaha, dan pemerintah.

4. Kepariwisataan adalah keseluruhan kegiatan yang terkait dengan pariwisata dan bersifat multidimensi dan multidisiplin yang muncul sebagai wujud kebutuhan setiap orang dan negara serta interaksi antara wisatawan, masyarakat setempat, sesama wisatawan, pemerintah, daerah, dan pengusaha.

Provinsi Gorontalo merupakan salah satu provinsi yang memiliki beragam tempat wisata yang menarik dan banyak di kunjungi oleh wisatawan. Provinsi ini memiliki banyak potensi wisata seperti paranorma dan keindahan alam di daerah kabupaten. Dilihat dari obyek dan daya tarik, wisata alam memiliki potensi yang sangat bagus untuk di kembangkan dan dapat berperan penting dalam meningkatkan pariwisata di Gorontalo. Salah satu daerah wisata adalah Botutonuo yang 
terletak di kecamatan Kabila Bone Kabupaten Bone Bolango yang terkenal dengan wisata pantainya dan memiliki berbagai ragam sumber daya alam, sebagai obyek dan daya tarik wisata. Sumber daya alam tersebut merupakan salah satu aset potensial kepariwisataan nasional.

Obyek wisata ini memunculkan sebuah tantangan pada generasi sekarang, Agar kiranya mampu mengembangkan dan mengelola potensi wisata tersebut. Sehingga tempat wisata tersebut dapat dijadikan sebagai sarana pendapatan bagi masyarakat setempat. Wisata pantai di Desa Botutonuo adalah wisata yang hanya di kelola oleh masyarakat tanpa campur tangan dari pihak pemerintah, baik pemerintah pusat maupun pemerintah daerah dan hal demikian dapat membuat peluang besar untuk mengelola wisata pantai tersebut dan meniptakan lapangan kerja, dalam rangka meningkatkan ekonomi masyarakat (Maku, D. \& Pariono, A. 2018)

\section{Peran Pariwisata dalam Perekonomian}

Menurut Salah Wahab dalam bukunya Tourism Management (1976:12) dalam Ismayanti (2010) mengatakan: "It is an important factor of economic development, as it motivates the development of several sectors on the national economy." Pariwisata merupakan faktor penting dalam pembangunan ekonomi suatu negara, karena mendorong perkembangan beberapa sektor perekonomian nasional (Yoeti, 2008), misalnya:

a) Peningkatan kegiatan perekonomian sebagai akibat dibangunnya prasarana dan sarana demi pengembangan pariwisata, sehingga memungkinkan orang-orang melakukan aktivitas ekonominya dari suatu tempat ke tempat lainnya, baik dalam satu wilayah negara tertentu, maupun dalam kawasan internasional sekali pun.

b) Meningkatkan industri-industri baru yang erat kaitannya dengan pariwisata seperti misalnya: transportasi, akomodasi, yang akhirny akan menciptakan permintaan baru seperti: trasportasi wisatawan dan perlengkapan hotel.

c) Meningkatkan hasil pertanian dan peternakan untuk kebutuhan hotel dan restoran, seperti sayur, buahbuahan, bunga, telur, daging, dan lainnya karena semakin banyaknya orang yang melakukan perjalanan wisata.

d) Meningkatkan permintaan terhadap souvenir, kerajinan tangan, dan lainlain.

e) Memperluas barang-barang lokal untuk lebih dikenal oleh dunia internasional termasuk makanan dan minuman, seperti: Ukiran Jepara, Patung Bali, Batik Pekalongan, atau Sate Madura.

f) Meningkatkan perolehan devisa negara sehingga dapat mengurangi beban defisit neraca pembayaran.

g) Memberikan kesempatan kerja, kesempatan berusaha, peningkatan penerimaan pajak bagi pemerintah, dan peningkatan pendapatan nasional.

h) Mempercepat perputaran perekonomian pada negara penerima kunjungan wisatawan.

i) Dampak pengganda yang ditimbulkan dari pengeluaran 
wisatawan, sehingga memberi dampak positif bagi pertumbuhan daerah tujuan wisata yang dikunjungi wisatawan.

Faktor dan Karakteristik yang Mempengaruhi Permintaan Pariwisata Permintaan dalam

kepariwisataan dapat dibagi atas dua, yaitu potential demand dan actual demand. Yang dimaksud dengan potential demand adalah sejumlah orang yang berpotensi untuk melakukan perjalanan wisata (karena memiliki cukup waktu luang dan tabungan yang relatif cukup). Sedangkan actual demand adalah orang yang sedang melakukan perjalanan wisata pada suatu daerah tujuan wisata tertentu. Kedua permintaan tersebut dipengaruhi oleh beberapa faktor yang terbagi menjadi dua seperti uraian berikut (Yoeti, 2008):

a) Faktor Umum Permintaan Pariwisata Secara umum, permintaan terhadap barang dan jasa pariwisata banyak tergantung oleh kekuatan untuk membeli, struktur demografi dan tren, faktor sosial dan kultur, motivasi perjalanan dan budaya lokal, dan kesempatan perjalanan dan biaya perjalanan.

b) Faktor Khusus Permintaan Pariwisata Faktor-faktor yang akan menentukan permintaan khusus terhadap daerah tujuan wisata tertentu yang akan dikunjungi biasanya ditentukan oleh harga, daya tarik wisata, kemudahankemudahan dalam berwisata (accessibilities), layanan sebelum kunjungan dan informasi, dan citra destinasi wisata.
Karakteristik permintaan perjalanan pariwisata diantaranya seperti dijelaskan sebagai berikut (Yoeti, 2008):

1. Elastisitas Permintaan pariwisata sangat elastis, artinya permintaan itu menunjukkan elastisitas langsung dengan besarnya pendapatan disatu sisi dan biaya perjalanan disisi yang lain sehingga dapat diketahui korelasi antara suatu peningkatan harga dengan turunnya permintaan melakukan perjalanan wisata dan sebaliknya. Permintaan wisata lebih elastis terutama pada daerah tujuan wisata yang favorit dan daerah tujuan wisata yang masih baru daripada daerah tujuan wisata yang kurang favorit.

2. Sensitivitas Permintaan pariwisata sangat sensitif dengan keadaan sosial, politik, dan keamanan negara yang akan dikunjungi. Hal ini sangat logis, karena seperti kita ketahui wisatawan itu merupakan orang yang akan melakukan 15 perjalanan untuk mencari kesenangan sehingga apabila terdapat sesuatu yang mengancam jiwa maka dapat mengakibatkan seseorang untuk mengundurkan diri untuk melakukan perjalalan wisata ke daerah tujuan wisata tersebut.

3. Musiman Permintaan pariwisata juga ditentukan oleh musim ramai (peak season) dan musim sepi (off season). Musim ramai terjadi pada hari-hari libur sekolah atau libur akhir tahun seperti Natal dan Tahun Baru. Pada musim ramai permintaan maningkat dari hari-hari biasanya.

4. Ekspansi Kecenderungan peningkatan wisatawan dalam melakukan perjalanan wisata dipengaruhi oleh kemajuan 
teknologi seperti teknologi penerbangan, informasi, komunikasi, bertambahnya waktu luang atau semakin singkatnya waktu kerja, dan semakin meningkatnya kesadaran terhadap lingkungan hidup.

\section{Faktor dan Karakteristik yang} Mempengaruhi Penawaran Pariwisata

Menurut Salah Wahab (1977)

dalam Oka A. Yoeti (2008), komponen penawaran dalam pariwisata dapat 16 bersumber dari alam atau buatan atau kreasi manusia, yang dijelaskan sebagai berikut:

1. Natural Amenities Yang termasuk dalam kelompok ini diantaranya adalah iklim, pemandangan, flora, fauna, dan sumberdaya yang berkhasiat.

2. Man-made Supply Yang termasuk dalam kelompok ini diantaranya adalah sejarah, budaya, religi, infrastruktur, fasilitas transportasi, superstructure, dan tata cara hidup masyarakat.

3. Daya Tarik Wisata Yang termasuk dalam kelompok ini diantarany adalah kekayaan alam, bangunan dengan arsitektur yang menarik, dan budaya lokal.

4. Fasilitas Pelayanan di daerah Tujuan Wisata Yang termasuk dalam kelompok ini diantaranya adalah akomodasi, restoran, bar, kafe, transportasi pada daerah tujuan wisata, fasilitas olah raga dan aktivitas lainnya, dan pedagang eceran.

5. Aksesibilitas Yang termasuk dalam kelompok ini adalah pelayanan visa kunjungan, tersedianya penerbangan langsung, prasarana industri pariwisata, pelayanan imigrasi dan bea cukai, serta pelayanan informasi pariwisata.

\section{Kebijakan terkait Pariwisata di Indonesia}

Berdasarkan Rencana Pembangunan Jangka Panjang Nasional 2005-2025, semua sektor pembangunan di Indonesia harus menerapkan prinsip pembangunan keberlanjutan termasuk sektor pariwisata. Upaya penerapan prinsip pembangunan keberlanjutan ini semata-mata dilakukan untuk alasan supaya kegiatan ekonomi di Indonesia mampu mendorong peningkatan kesejahteraan masyarakat dan pertumbuhan ekonomi nasional melalui sektor pariwisata. Untuk menjamin terlaksananya pariwisata yang berkelanjutan, telah dikeluarkan Peraturan Pemerintah Kepariwisataan Nasional RI No.50 Tahun 2011 tentang Rencana Induk Pembangunan Kepariwisataan Nasional (Ripparnas) Tahun 2010-2025. Dalam Ripparrnas ditegaskan lima hal utama untuk mengarahkan pembangunan kepariwisataan yaitu: (1) berdasarkan prinsip pembangunan kepariwisataan yang berkelanjutan, (2) dengan orientasi pada upaya peningkatan pertumbuhan, peningkatan kesempatan kerja, pengurangan kemiskinan, serta pelestarian lingkungan, (3) dengan tata kelola yang baik, (4) secara terpadu, lintas sektor, lintas daerah, dan lintas pelaku, (5) dengan mendorong kemitraan sektor publik dan privat (Teguh dan Avenzora, 2013).

Dalam menunjang tercapainya tujuan pembangunan pariwisata yang tercantum dalam RIPPARNAS 20102025, pemerintah memutuskan dalam RPJMN 2015-2019, sasaran-sasaran 
pembangunan pariwisata untuk meningkatkan daya saing pariwisata. Uraian sasaran pembangunan pariwisata diantaranya yaitu kontribusi sektor pariwisata terhadap PDB Nasional mencapai 8 persen, 20 juta wisatawan mancanegara, 275 juta perjalanan wisatawan nusantara, dan perolehan devisa sebesar Rp 260 triliun (Badan Pengawas Keuangan Dan Pembanguan, 2015).

\section{Kerangka Pikir}

Obyek wisata pantai Botutonuo Kabupaten Bone Bolango di awali dengan mengidentifikasi rumusan masalah untuk dicocokkan dengan penentuan tujuan penelitian sehingga akan memudahkan untuk menentukan ruang lingkup penelitian. Setelah menentukan ruang lingkup penelitian maka dilakukan studi literatur. Studi literatur tersebut terdiri dari metode analisis swoot dan teori pendukung pariwisata dan potensi pengembangannya.

Metode analisis SWOT diidentifikasi berdasarkan dua kriteria yakni faktor internal dan eksternal. Faktor internal dijabarkan melalui 1. Aksebilitas, 2. Budaya dan Sosial, 3. Fasilitas, 4. Kondisi Alam. dan Faktor eksternal dijabarkan dengan 1. Promosi, 2. Masyarakat Sekitar, 3. Pemerintah. Sehingga dari hal tersebut kita dapat mendapatkan strategi pengembangan pariwisata Pantai Botutonuo.

Untuk mempermudah memahami kerangka pikir tersebut, Bisa dilihat pada bagan kerangka pikir dibawah ini:

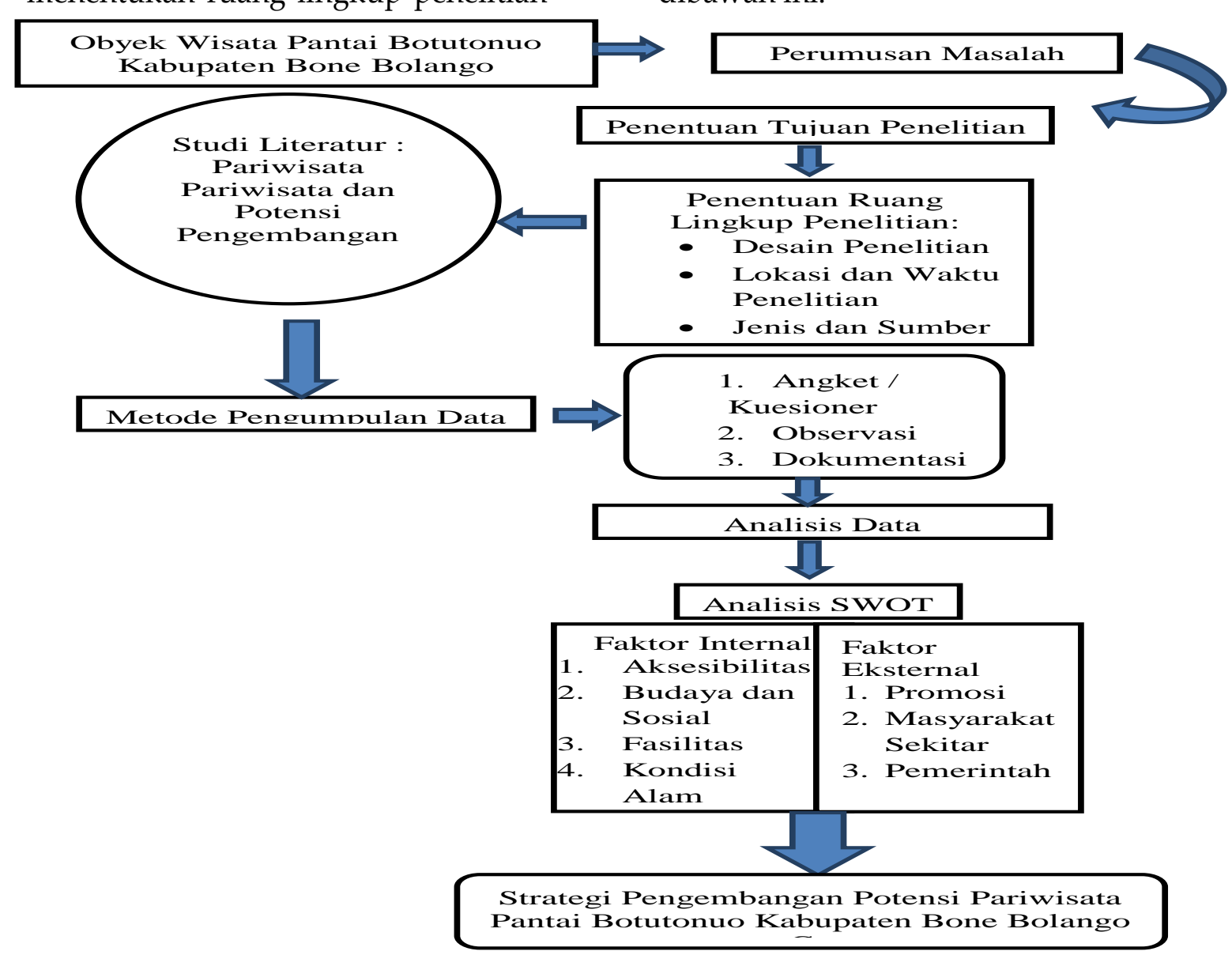




\section{Metode Penelitian}

Penelitian ini menggunakan metode penelitian deskriptif kuantitatif. Penelitian analisis faktor internal dan faktor eksternal analisis SWOT dangan interaksi matriks IFAS (Internal Factor Analysis System) dan EFAS (External Factor Analysis System). (Asri Dwi, 2010). Lokasi penelitian ini dilaksanakan di Kabupaten Bone Bolango. Tepatnya di obyek wisata Pantai Botutonuo yang dianggap dapat menarik perhatian wisatawan.

Berdasarkan pendekatan SWOT, yang menjadi responden untuk melakukan pembobotan adalah seorang ahli (expert). Yang dimaksud dengan expert disini tidak harus seseorang yang pakar pada satu bidang keilmuan tertentu, melainkan orang yang tahu betul akan permasalahan yang hendak diteliti. Dalam konteks pengembangan Pantai Botutonuo Kabupaten Bone Bolango, expert yang dimaksud dalam penelitian ini adalah orang yang paham benar mengenai kawasan pariwisata Pantai Botutonuo Kabupaten Bone Bolango. Expert dalam hal ini adalah Dinas Pariwisata Kabupaten Bone Bolango 1 orang, serta masyarakat sekitar Pantai Botutonuo 40 orang. Untuk itu, pengelola obyek wisata, seorang yang ahli di bidang pariwisata, masyarakat sekitar obyek wisata, dan wisatawan merupakan orang yang tepat untuk dijadikan responden dalam menentukan bobot pangaruh, faktor, variabel, dan indikator yang digunakan untuk pemeringkatan strategi pengembangan Pariwisata Pantai Botutonuo Kabupaten Bone Bolango.
Metode Pengolahan dan Analisis Data Analisis SWOT didasarkan pada logika yang dapat memaksimalkan kekuatan (Strenghts) dan peluang (Opportunities), namun secara bersamaan dapat meminimalkan kelemahan (Weaknesses) dan ancaman (Threats). Proses pengambilan keputusan strategis selalu berkaitan dengan pengembangan misi, tujuan, strategi, dan kebijakan perusahaan. Dengan demikian, perencana strategis harus menganalisis faktor-faktor strategis perusahaan (kekuatan, kelemahan, peluang, dan ancaman) dalam kondisi yang ada saat ini. Hal ini disebut dengan Analisis Situasi. Model yang paling popular untuk analisis situasi adalah Analisis SWOT (Freddy Rangkuti : 2015).

Matriks SWOT menggambarkan secara jelas bagaimana peluang dan ancaman eksternal yang dihadapi oleh perusahaan dapat disesuaikan dengan kekuatan dan kelemahan yang dimiliki (Marimin, 2004).

Terdapat empat tahapan dalam membentuk matrik SWOT yaitu:

1. Mencocokan kekuatan internal dengan peluang eksternal dan mencatat resultan strategi SO.

2. Mencocokan kelamahan internal dengan peluang eksternal dan mencatat resultan strategi WO.

3. Mencocokan kekuatan internal dengan ancaman eksternal dan mencatat resultan strategi ST.

4. Mencocokan kelemahan internal dengan ancaman dan mencatat resultan strategi WT. 


\begin{tabular}{|c|c|c|}
\hline IFAS & $\begin{array}{l}\text { STRENGTH } \\
\text { (5)Tentukan 5-10 faktor- } \\
\text { faktorkekuatan internal }\end{array}$ & $\begin{array}{l}\text { WEAKNESS } \\
\text { (W)Tentukan5- } \\
\text { 10faktor- } \\
\text { faktorkelemahan } \\
\text { internal }\end{array}$ \\
\hline $\begin{array}{l}\text { OPPORTUNITY } \\
\text { (O)Tentukan 5-10 } \\
\text { faktor-faktor peluang } \\
\text { eksternal }\end{array}$ & $\begin{array}{l}\text { Strategi SO Ciptakan } \\
\text { strategi yang } \\
\text { menggunakan kekuatan } \\
\text { untuk memanfaatkan } \\
\text { peluang }\end{array}$ & $\begin{array}{l}\text { Strategi WO Ciptakan } \\
\text { strategi yang } \\
\text { meminimalkan } \\
\text { kelemahan untuk } \\
\text { memanfaatkan } \\
\text { peluang }\end{array}$ \\
\hline $\begin{array}{l}\text { THREAT } \\
\text { (T)Tentukan 5-10 } \\
\text { faktor-faktor } \\
\text { ancaman eksternal }\end{array}$ & $\begin{array}{l}\text { Strategi ST Ciptakan } \\
\text { strategi yang } \\
\text { menggunakan kekuatan } \\
\text { untuk mengatasi } \\
\text { ancaman }\end{array}$ & $\begin{array}{l}\text { Strategi WTCiptakan } \\
\text { strategi yang } \\
\text { meminimalkan } \\
\text { kelemahan dan } \\
\text { menghindari ancaman }\end{array}$ \\
\hline
\end{tabular}

Sumber : Rangkuti (1997)

Pembahasan

Analisis Deskriptif (Faktor

Penghambat \& Pendorong Pariwisata

Pantai Botutonuo Di Kabupaten Bone

Bolango

1.Faktor Penghambat Pariwisata Pantai Botutonuo Di Kabupaten Bone

Bolango

a. Minimnya Moda Transportasi Pada

Kawasan Wisata

Kurangnya moda transportasi yang disediakan oleh pihak pengelola maupun pihak pemerintah dalam mendukung usaha pengembangan lokasi wisata belum juga dilakukan secara maksimal. Penggunaan moda transportasi oleh pengunjung (wisatawan) dalam mengunjungi lokasi wisata selama ini masih dilakukan dengan penggunaan moda transportasi sendiri. Harapannya moda transportasi dalam bentuk Bus Pariwisata dapat disediakan oleh pengelola maupun pihak pemerintah sebagai instansi yang bertanggung jawab dalam memperkenalkan daerah wisata di Kabupaten Bone Bolango.

b.Peran Lembaga Pengelola Pariwisata Pada pariwisata pantai di Botutonuo (Kabupaten Bone Bolango) seluruh pariwisata pantai yang juga termasuk dalam desa wisata ini dikelola oleh masyarakat yang tergabung dalam Kelompok Sadar Wisata (Pokdarwis). Secara umum, peran lembaga pengelola khususnya swasta belum terlihat. Selain itu, peran lembaga pemerintah sendiri juga masih kurang karena belum semua destinasi wisata pantai dikelola pemerintah. Hal ini menjadikan variabel terkait lembaga pengelola pariwisata menjadi faktor penghambat karena dalam pengelolaan belum melibatkan elemen pemerintah daerah dan lembaga swasta.

c. Pemanfaatan Media Promosi (Ketidak Optimalan Pemanfaatan Media Dalam Promosi Wisata)

Promosi wisata penting untuk menawarkan destinasi wisata kepada masyarakat umum agar mereka tertarik untuk mengunjungi destinasi wisata tersebut. Khusus obyek wisata pantai Botutonuo belum terlihat adanya bentuk promosi yang dilakukan. Padahal apabila ingin semakin berkembang, harus bisa memanfaatkan semua jenis media untuk melakukan promosi wisata. Untuk kedepannya diharapkan para pengelola dapat mengoptimalkan media promosi yang ada. Hal itu bertujuan agar pariwisata pantai Botutonuo yang ada di Kabupaten Bone Bolango dapat lebih berkembang dan diketahui oleh banyak kalangan masyarakat.

d. Sampah Berserakan Yang Belum Terkontrol Dan Menyebabkan Daya Tarik Wisatawan Menurun.

Kesadaran masyarakat pengunjung (wisatawan) akan pentingnya 
perilaku bersih belum menjadi perhatian dari kalangan wisatawan. Sampah bekas makanan yang berserakan disemua sudut lokasi wisata sangat mengganggu kenyamanan dalam menikmati suasasa pantai dan obyek wisata yang ditawarkan. Hal ini juga tidak didukung oleh pihak pengelola dalam menyediakan fasilitas sampah di dalam kawasan lokasi wisata.

e. Ketidak Tersediaan Fasilitas Kebencanaan Pesisir Dan Tindakan Mitigasi Bencana Pesisir Pantai.

Daerah-daerah pantai, pesisir dan pulau-pulau kecil merupakan daerah yang rawan bencana alam seperti gempa, banjir pasang dan angin besar sehingga dibutuhkan fasilitas mitigasi bencana. Semakin tinggi tingkat kerawanan bencana yang ditimbulakan maka seharusnya semakin lengkap pula fasilitas terkait dengan mitigasi bencana. Hal ini bertujuan untuk mencegah adanya kerugian yang berupa kerugian fisik karena infrastrukur yang rusak ataupun kerugian berupa adanya korban jiwa.

2. Faktor Pendorong Pariwisata Pantai Botutonuo Di Kabupaten Bone Bolango

a. Aksesbilitas Jalan Menuju Lokasi Wisata

Salah satu faktor yang mendorong perkembangan pariwisata adalah jaringan jalan yang mana merupakan sirkulasi utama yang menghubungkan antar objek wisata sehingga memudahkan wisatawan menuju objek wisata tersebut. Akses jalan menuju lokasi wisata pantai Botutonuo memiliki dan didukung dengan rambu penunjuk arah yang baik.

Posisi geografis destinasi wisata pantai Botutonuo juga menjadi faktor yang mempengaruhi perkembangan pariwisata karena hal ini menjelaskan mengenai hubungan antara segmen pasar dan destinasi pariwisata. Semakin dekat jarak asal wisatawan dengan destinasi wisata maka mobilitasnya semakin tinggi karena mudah di jangkau.

b. Pelayanan Baik Pelaku Usaha/ masyarakat Terhadap Wisatawan Sikap keramahan pelayanan pelaku usaha dan masyarakat desa sekitar lokasi wisata pantai Botutonuo di Kabupaten Bone Bolango dilihat dari ketersediaan rumah makan karena rumah makan merupakan bentuk fasilitas yang disediakan untuk wisatawan dan dilayani langsung oleh masyarakat. Berdasarkan pendapat wisatawan, pelayanan yang diberikan sudah baik dan masyarakat lokal pun ramah dalam memberikan pelayanan.

c. Ketersediaan Sarana Dan Prasarana Pariwisata

Ketersediaan sarana dasar pariwisata sangat dibutuhkan oleh wisatawan selama mereka berada di daerah/ lokasi destinasi wisata. Sarana wisata yang tersedia merupakan usaha dan kewenangan dari pengelola dalam dalam menyediakan hal tersebut. Pada dasarnya sarana dasar wisata tidak hanya dinilai dari ketersediaan namun juga kualitas pelayanannya. Berdasarkan hasil observasi dan wawancara dengan pihal pengelola didapat bahwa ketersediaan sarana dasar pariwisata di Pantai Botutonuo meliputi: warung makan, toilet, area 
parkir, pos keamanan dan Home Stay/ penginapan.

Prasarana penunjang pariwisata juga diperlukan untuk memenuhi kebutuhan wisatawan selama berada di destinasi pariwisata. Prasarana dasar pendukung wisata terdiri atas: penyediaan air bersih, jaringan listrik, jaringan drainase, dan tempat sampah. Untuk prasarana minimal yang tersedia di destinasi wisata yaitu dua prasarana meliputi jaringan air bersih dan jaringan listrik.

d. Peran Masyarakat Yang Aktif Untuk Mendukung Perkembangan Pariwisata

Selama obyek wisata Pantai Botutonuo dibuka untuk umum (wisatawan) aman dari tindak kejahatan. Aman yang dimaksud yaitu tidak adanya tindak kejahatan yang terjadi seperti pencurian atau pemalakan. Hal ini menunjukkan bahwa tingkat keamanan wisatawan dari segi sosial baik sehinggamenjadi faktor pendorong dalam perkembangan pariwisata pantai karena apabila destinasi wisata aman maka pengunjung merasa aman dan nyaman selama berwisata.

Disamping itu peran serta masyarakat yang aktif yang tergabung dalam Kelompok Sadar Wisata (Pok Darwis) yang merupakan organisasi masyarakat yang peduli akan potensi wisata di daerahnya. Pok Darwis ini memiliki peranan penting dalam perkembangan pariwisata pantai selama ini karena mereka yang mengelola pariwisata pantai itu sendiri, mulai dari memunculkan ide untuk menambah atraksi wisata hingga ke upaya usulan penambahan fasilitas yang diajukan ke pemerintah daerah.

e. Adanya Dukungan Anggaran Dari Pemerintah

Dukungan dan keinginan pemerintah daerah (PEMDA) dalam hal pengembangan obyek pariwisata di Daerah Kabupaten Bone Bolango sangat tinggi. Hal ini terlihat dari perhatian pemerintah daerah dalam menyediakan anggaran dalam rangka memperluas informasi tentang keberadaan obyek wisata dan pengembangannya merupakan hal yang sangat mendukung majunya industri pariwisata di daerah Kabupaten Bone Bolango.

\section{Pengkategorian Item SWOT}

Menurut Sugiyono (2014) kriteria interpretasi skor berdasarkan jawaban responden dapat ditentukan dengan skor maksimum setiap kuesioner adalah 5 dan skor minimum adalah 1 maka dapat diketahui rentang skala adalah dengan meangalikan skor tertinggi dengan jumlah responden dan mengalikan skor terendah dengan jumlah responden. Skor minimal, skor maksimal danrentangskor didapatkan dari perhitungan berikut ini:

a. Skor minimum $=1 \times 40=40(20 \%)$

b. Skor Maksimum $=5 \times 40=200(100 \%)$

c. Rentang skor $=(200-40): 4=40(20 \%)$

Sehingga berdasarkan rentang skala tersebut dibuat penilaian sebagaimana terlihat pada tabel 4.1 berikut:

Tabel 4.1: Interprestasi Skor

\begin{tabular}{|c|c|c|}
\hline No & Persentase Skor & Kriteria \\
\hline 1 & $36,01 \%-52,00 \%$ & Tidak \\
\hline 2 & $52,01 \%-68,00 \%$ & Kurang \\
\hline
\end{tabular}




\begin{tabular}{|c|c|c|}
\hline 3 & $68,01 \%-84,00 \%$ & Cukup \\
\hline 4 & $84,01 \%-100,00 \%$ & Baik \\
\hline
\end{tabular}

Sumber: Data Olahan, 2020

Berdasarkan tabel di atas, maka dapat diketahui kriteria dari tiap pernyataan, indikator maupun variabel. Perhitungan skor dapat diperoleh melalui perhitungan berikut ini:

$\%$ Skor Pernyataan $=\frac{\text { Skor Aktual }}{\text { Skor Ideal }} \times 100 \%$

Keterangan:

a. Skor Aktual adalah skor yang diperoleh dari jawaban seluruh responden atas kusioner yang telah diajukan.

b. Skor ideal adalah skor maksimum atau skor tertinggi yang mungkin diperoleh jika semua responden memilih jawaban dengan skor tertinggi.

Penjabaran mengenai item dalam SWOT untuk strategi pengembangan pariwisata dan ekonomi masyarakat di Pantai Botutonuo Kabupaten Bone Bolango disajikan berikut ini:

\section{Faktor Internal}

Hasil jawaban responden mengenai faktor internal dalam pengembangan pariwisata dan ekonomi masyarakat di Pantai Botutonuo Kabupaten Bone Bolango dapat disajikan berikut ini:

Tabel Hasil Deskriptif Faktor Internal Pengembangan Pariwisata dan Ekonomi Masyarakat

\begin{tabular}{|c|c|c|c|c|c|c|c|c|c|}
\hline \multirow[b]{2}{*}{ Indikator } & \multicolumn{8}{|c|}{ SKOR PERNYATAAN } & \multirow[t]{2}{*}{ Kriteria } \\
\hline & $\begin{array}{l}\mathrm{T} \\
\mathrm{P} \\
\end{array}$ & \begin{tabular}{|l}
$\mathrm{K}$ \\
$\mathrm{P}$ \\
\end{tabular} & $\begin{array}{l}\mathrm{C} \\
\mathrm{P} \\
\end{array}$ & $\mathbf{P}$ & $\begin{array}{l}\mathrm{S} \\
\mathrm{P}\end{array}$ & Aktual & Ideal & $\%$ & \\
\hline Akse & 0 & 6 & 67 & 87 & 40 & 761 & 1,000 & $76.10 \%$ & $\begin{array}{c}\text { Cukup } \\
\text { Baik }\end{array}$ \\
\hline $\begin{array}{c}\text { Budaya dan } \\
\text { Sosial }\end{array}$ & 0 & 7 & 51 & 86 & 56 & 791 & 1,000 & $79.10 \%$ & $\begin{array}{c}\text { Cukup } \\
\text { Baik }\end{array}$ \\
\hline Fasilitas & 0 & 9 & 59 & 77 & 55 & 778 & 1,000 & $77.80 \%$ & $\begin{array}{c}\text { Cukup } \\
\text { Baik }\end{array}$ \\
\hline $\begin{array}{l}\text { Kondisi } \\
\text { Alam }\end{array}$ & 0 & 11 & 90 & 76 & 23 & 711 & 1,000 & $71.10 \%$ & $\begin{array}{c}\text { Cukup } \\
\text { Baik }\end{array}$ \\
\hline
\end{tabular}

Sumber Pengolahan Data Primer, 2020

Keterangan :

TP : Tidak Puas KP: Kurang Puas

$\mathrm{CP}$ : Cukup Puas $\quad \mathrm{P}$ : Puas

SP : Sangat Puas

Berdasarkan hasil pada tabel di atas, maka dapat dijelaskan hasil analisis berikut ini:

\section{Aksesibilitas}

Berdasarkan hasil jawaban dari responden ditemukan bahwa skor capaian aksesibilitas sebesar $76,10 \%$ yang berada pada kriteria yang cukup baik. Hal ini menunjukan bahwa akses ke Pantai Botutonuo Kabupaten Bone Bolango pada dasarnya tidak begitu jauh namun jalannya rawan akan adanya bahaya sehingga perlu diupayakan adanya pelebaran jalan atau akses ke lokasi wisata yang kondusif bagi wisatawan. Dari 5 pernyataan mengenai aksesibilitas terdapat 3 faktor kelemahan dan 2 faktor lainnya sebagai kekuatan dalam pengembangan pariwisata dan ekonomi masyarakat di Pantai Botutonuo Kabupaten Bone Bolango.

2. Budaya dan Sosial

Berdasarkan hasil jawaban dari responden ditemukan bahwa skor capaian budaya dan sosial sebesar $79,10 \%$ yang berada pada kriteria yang cukup baik. Hal ini menunjukan bahwa kondisi budaya dan sosial masyaakat yang sangat antusias dengan adanya wisatawan, dimana masyarakat sekitar juga sangat ramah kepada pengunjung. Dari 5 pernyataan mengenai budaya dan sosial terdapat 1 faktor kelemahan dan 4 faktor lainnya sebagai kekuatan dalam pengembangan pariwisata dan ekonomi masyarakat di Pantai Botutonuo Kabupaten Bone Bolango. 


\section{Fasilitas}

Berdasarkan hasil jawaban dari responden ditemukan bahwa skor capaian fasilitas sebesar $77,80 \%$ yang berada pada kriteria yang cukup baik. Hal ini menunjukan bahwa fasilitas yang tersedia di Pantai Botutonuo Kabupaten Bone Bolango masih belum begitu memadai sehingga perlu adanya anggaran untuk pengembangan fasilitas oleh pemerintah Kabupaten Bone Bolango bekerja sama dengan pemerintah desa Botutonuo dan masyarakat sekitar. Dari 5 pernyataan mengenai fasilitas terdapat 2 faktor kelemahan dan 3 faktor lainnya sebagai kekuatan dalam pengembangan pariwisata dan ekonomi masyarakat di Pantai Botutonuo Kabupaten Bone Bolango.

4. Kondisi alam

Berdasarkan hasil jawaban dari responden ditemukan bahwa skor capaian kondisi alam sebesar $71,10 \%$ yang berada pada kriteria yang cukup baik. Hal ini menunjukan bahwa kondisi alam di Pantai Botutonuo Kabupaten Bone Bolango perlu untuk membuat wisatawan penuh kehatihatian karena pada dasarnya semua wisata pantai memiliki bahaya tersendiri sehingga perlu adanya intervensi pemerintah dalam mengupayakan atau mereduksi dampak dari kondisi ekstrim alam yang dapat berdampak pada wisatawan. Dari 5 pernyataan mengenai kondisi alam terdapat 4 faktor kelemahan dan 1 faktor lainnya sebagai kekuatan dalam pengembangan pariwisata dan ekonomi masyarakat di Pantai Botutonuo Kabupaten Bone Bolango.

\section{Faktor Eksternal}

Hasil jawaban responden mengenai faktor eksternal dalam pengembangan pariwisata dan ekonomi masyarakat di Pantai Botutonuo Kabupaten Bone Bolango dapat disajikan berikut ini:

Tabel Hasil Deskriptif Faktor

Eksternal Pengembangan Pariwisata dan Ekonomi Masyarakat

\begin{tabular}{|c|c|c|c|c|c|c|c|c|c|}
\hline \multirow{2}{*}{ Indikator } & \multicolumn{7}{|c|}{ SKOR PERNYATAN } & Kriteria \\
\cline { 2 - 9 } & $\mathrm{T}$ & $\mathrm{K}$ & $\mathrm{C}$ & $\mathrm{P}$ & $\mathrm{S}$ & Aktual & Ideal & $\%$ & \\
\hline Promosi & 1 & 2 & 57 & 116 & 24 & 760 & 1,000 & $76.00 \%$ & $\begin{array}{c}\text { Cukup } \\
\text { Baik }\end{array}$ \\
\hline Masyarakat & 0 & 4 & 49 & 96 & 51 & 794 & 1,000 & $79.40 \%$ & $\begin{array}{c}\text { Cukup } \\
\text { Baik }\end{array}$ \\
\hline Pemerintah & 0 & 1 & 63 & 85 & 51 & 786 & 1,000 & $78.60 \%$ & $\begin{array}{c}\text { Cukup } \\
\text { Baik }\end{array}$ \\
\hline
\end{tabular}

Sumber Pengolahan Data Primer, 2020

Keterangan :

TP : Tidak Puas

$$
\text { KP : Kurang Puas }
$$

CP : Cukup Puas

$\mathrm{P}$ : Puas

SP : Sangat Puas

Berdasarkan hasil pada tabel di atas, maka dapat dijelaskan hasil analisis berikut ini:

\section{Promosi}

Berdasarkan hasil jawaban dari responden ditemukan bahwa skor capaian promosi sebesar $76,00 \%$ yang berada pada kriteria yang cukup baik. Hal ini menunjukan bahwa banyaknya promosi yang dilakukan oleh berbagai elemen atas Pantai Botutonuo Kabupaten Bone Bolango termasuk oleh mereka wisatawan yang mengupload foto saat berada di pantai tersebut. Dari 5 pernyataan mengenai promosi terdapat 3 faktor ancaman dan 2 faktor lainnya sebagai peluang dalam pengembangan pariwisata dan ekonomi masyarakat di Pantai Botutonuo Kabupaten Bone Bolango. 


\section{Masyarakat}

Berdasarkan hasil jawaban dari responden ditemukan bahwa skor capaian masyarakat sebesar 79,40\% yang berada pada kriteria yang cukup baik. Hal ini menunjukan bahwa masyarakat di sekitar Pantai Botutonuo Kabupaten Bone Bolango mampu memberikan kontribusi yang cukup bagi adanya pengembangan wisata dan kemudian masyarakat pula yang merasakan manfaat ekonomi atas wisata tersebut. Dari 5 pernyataan mengenai masyarakat sekitar terdapat 2 faktor ancaman dan 3 faktor lainnya sebagai peluang dalam pengembangan pariwisata dan ekonomi masyarakat di Pantai Botutonuo Kabupaten Bone Bolango.

\section{Pemerintah}

Berdasarkan hasil jawaban dari responden ditemukan bahwa skor capaian pemerintah sebesar $78,60 \%$ yang berada pada kriteria yang cukup baik. Hal ini menunjukan bahwa pemerintah senantiasa memperhatikan pengembangan wisata Pantai Botutonuo Kabupaten Bone Bolango yang dibuktikan dengan adanya anggaran yang cukup besar pada tahun 2020 untuk pengembangan wisata. Dari 5 pernyataan mengenai pemerintah terdapat 2 faktor ancaman dan 3 faktor lainnya sebagai peluang dalam pengembangan pariwisata dan ekonomi masyarakat di Pantai Botutonuo Kabupaten Bone Bolango.

\section{Identifikasi Faktor Internal Pantai} Botutonuo Kabupaten Bone Bolango

Faktor internal ini mempengaruhi terbentuknya strengths and weakness (S and $W$ ).

1. Kekuatan
Faktor-faktor internal khususnya mengenai kekuatan dalam strategi pengembangan pariwisata dan ekonomi masyarakat yang diberikan oleh Pantai Botutonuo Kabupaten Bone Bolango dapat dijabarkan berikut ini:

a. Sepanjang memasuki kawasan objek wisata, ada petunjuk jalan bagi wisatawan

b. Keadaan lingkungan yang kondusif bagi wisatawan

c. Budaya sekitar objek wisata yang bisa menerima keberadaan wisatawan

d. Masyarakat mau membaur dengan wisatawan

e. Masyarakat sangat antusias dengan wiasatawan

f. Kerja sama antara masyarakat dan wisatawan dalam hal ekonomi

g. Adanya sarana untuk wisatawan beristirahat

h. Adanya fasilitas untuk mengeksplorasi objek wisata

i. Kondisi alam yang aman dan nyaman

2. Kelemahan

Faktor-faktor internal khususnya mengenai kelemahan dalam strategi pengembangan pariwisata dan ekonomi masyarakat di Pantai Botutonuo Kabupaten Bone Bolango dapat dijabarkan berikut ini:

a. Kondisi jalan yang baik untuk dilalui oleh wisatawan

b. Keadaan jalanan yang tidak rawan dengan kecelakaan

c. Jalan yang bebas dari hewan ternak yang berkeliaran di jalan

d. Tidak adanya pungutan yang memberatkan wisatawan

e. Adanya fasilitas ruangan ganti di objek wisata 
f. Adanya fasilitas pendukung bagi kegiatan wisatawan

g. Adanya fasilitas mempermudah transaksi keuangan wisatawan

h. Prospek wisata yang bisa lebih berkembang

i. Potensi ekonomi yang memadai di lokasi wisata

j. Bebas dari cuaca ekstrim terutama cuaca di pingggir pantai

k. Wisata aman dari hewan laut berbahaya

Berdasarkan hasil analisis lingkungan internal diperoleh dari lapangan faktor yang berupa kekuatan (Strengths) dan kelemahan (Weakneses) berpengaruh terhadap kelangsungan Pantai Botutonuo Kabupaten Bone Bolango.

Terkait faktor strategi internal yang menjadi kekuatan dan kelemahan oleh Pantai Botutonuo Kabupaten Bone Bolango, berdasarkan pengolahan data dapat dilihat bahwa nilai total dari faktor kekuatan adalah 1,3032 lebih kecil dari faktor kelemahan yaitu 1,4265. Hal ini menunjukkan bahwa Pantai Botutonuo Kabupaten Bone Bolango masih memiliki berbagai kelemahan untuk dijadikan sebagai suatu wisata yang unggul dan mendominasi di Kabupaten Bone Bolango terlebih lagi objek wisata ini masih belum begitu besar dampaknya bagi peningkatan PADes Desa Botutonuo dan juga bagi peningkatan PAD Kabupaten Bone Bolango bahkan kelemahan tersebut terlihat dari model koteks wisata yang kurang sesuai dan kurang representatif untuk wisata modern.

Identifikasi Faktor Eksternal Pantai Botutonuo Kabupaten Bone Bolango

Faktor eksternal ini mempengaruhi terbentuknya opportunities and threats
$(\mathrm{O}$ and $\mathrm{T})$. Faktor ini mencakup lingkungan industri dan lingkungan bisnis makro, ekonomi, politik, hukum, teknologi, kependudukan, dan sosial budaya.

1. Peluang

Faktor-faktor eksternal khususnya mengenai peluang dalam strategi pengembangan pariwisata dan ekonomi masyarakat di Pantai Botutonuo Kabupaten Bone Bolango dapat dijabarkan berikut ini:

a. Setiap ada hal unik baru senantiasa dipromosikan

b. Stigma positif dari objek wisata menarik minat masyarakat luas

c. Masyarakat sekitar memerlukan wisatawan untuk peningkatan ekonomi

d. Masyarakat menjadi perpanjangan tangan pemerintah daerah

e. Masyarakat turut andil dalam mencegah keselamatan wisatawan

f. Adanya komitmen program pengembangan wisata

g. Pemerintah melakukan acara atau ivent di lokasi wisata

h. Sosialisasi kepariwisataan dan tindak lanjut modal usaha ke masyarakat.

2. Ancaman

Faktor-faktor eksternal khususnya mengenai ancaman dalam strategi pengembangan pariwisata dan ekonomi masyarakat di Pantai Botutonuo Kabupaten Bone Bolango dapat dijabarkan berikut ini:

a. Adanya promosi oleh influencer wisata Gorontalo

b. Promosi oleh LSM pecinta wisata

c. Adanya kerja sama dalam promosi wisata dari semua pihak

d. Masyarakat merasa memiliki objek wisata 
e. Masyarakat sekitar tidak melakukan pungli

f. Adanya dukungan anggaran dari pemerintah

g. Melakukan kerja sama dengan kementerian pariwisata

Berdasarkan hasil analisis lingkungan eksternal diperoleh dari lapangan faktor yang berupa peluang (Opportunities) dan ancaman (Treatsh) berpengaruh terhadap kelangsungan Pantai Botutonuo Kabupaten Bone Bolango.

Terkait faktor strategi eksternal yang menjadi peluang dan ancaman oleh Pantai Botutonuo Kabupaten Bone Bolango, berdasarkan pengolahan data menunjukkan bahwa nilai faktor peluang yang dimiliki oleh Pantai Botutonuo Kabupaten Bone Bolango yakni 1,5034 lebih besar dibandingkan dengan faktor ancaman yang sebesar 1,2457. Hal ini menunjukkan bahwa adanya peluang yang besar bagi seluruh elemen dalam pengembangan pariwisata dan ekonomi masyarakat di Pantai Botutonuo Kabupaten Bone Bolango. Pengembangan dan peluang ini menjadi suatu aspek yang krusial karena dengan peluang yang besar ini maka dapat mereduksi berbagai kelemahan yang ada pada objek wisata sehingga akan mampu memberikan kontribusi dalam peningkatan ekonomi masyarakat.

Matriks SWOT Strategi pengembangan pariwisata dan ekonomi masyarakat Di Pantai Botutonuo Kabupaten Bone Bolango

Berdasarkan data yang di peroleh dilapangan tentang faktor-faktor internal dan eksternal Pantai Botutonuo Kabupaten Bone Bolango dalam mengembangkan strategi pengembangan pariwisata dan ekonomi masyarakat maka selanjutnya dapat menggunakan matriks SWOT untuk menyusun alternatif strategi dengan menggunakan empat strategi yakni Strengths (kekuatan), Opportunities (peluang), Weaknesses (kelamahan), Threats (ancaman). Data matriks menunjukkan 4 (empat) sel strategi alternatif yang dapat dijalankan oleh Pantai Botutonuo Kabupaten Bone Bolango yaitu:

1. Strategi SO (Strength-Opportunities) Strategi ini dibuat bersadarkan jalan pikiran perusahan, yaitu dengan memanfaatkan seluruh kekuatan utntuk merebut dan memanfaatkan peluang sebesar-besarnya.

a. Mengembangkan aksesibilitas yang baik dan nyaman bagi wisatawan

b. Membuat ivent dan pagelaran budaya secara berkelanjutan
2. Strategi
WO
(Weaknesses-
Opportunitties)

Strategi ini diterapkan berdasarkan pemanfaatan peluang yang ada dengan cara meminimalkan kelemahan yang ada.

a. Implementasi sapta pesona untuk wisata pantai Botutonuo

b. Membuat city Branding Pantai Botutonuo

c. Capacity Building bagi masyarakat sekitar dalam hal ekonomi kretaif berbasis masyarakat dan pariwisata

d. Master plan wisata dan pembangunan berkelanjutan

e. Peran kelembagaan pariwisata yang harus dioptimalkan

3. Strategi ST (Strength-Threatsh)

Ini adalah strategi dalam menggunakan kekuatan yang dimiliki dengan mengatasi ancaman.

a. Membuat regulasi untuk keberlanjutan wisata 
b. Melakukan promosi wisata secara berkelanjutan

\section{Strategi WT (Weaknesses-Threatsh)} Strategi ini didasarkan pada kegiatan yang bersifat defensif dan berusaha meminimalkan kelamahan yang ada serta menghindari ancaman yang ada. a. Pembuatan spot wisata baru yang bukan hanya bertema laut seperti spot foto di gunung dan lainnya

b. Penyediaan fasilitas dan berbagai sarana prasarana yang menarik Adapun hasil dari alternatif strategi di sajikan pada matriks berikut:

\begin{tabular}{|c|c|c|}
\hline \multirow{12}{*}{ EKSTERNAL } & Kekuatan (Strengths) & Kelemahan (Weaknesses) \\
\hline & $\begin{array}{l}\text { Sepanjang memasuki kawasan objek } \\
\text { wisata, ada petunjuk jalan bagi } \\
\text { wisatawan }\end{array}$ & $\begin{array}{l}\text { Kondisi jalan yang tidak baik untuk } \\
\text { dilalui oleh wisatawan }\end{array}$ \\
\hline & $\begin{array}{l}\text { Keadaan lingkungan yang kondusif } \\
\text { bagi wisatawan }\end{array}$ & $\begin{array}{l}\text { Keadaan jalanan yang rawan dengan } \\
\text { kecelakaan }\end{array}$ \\
\hline & $\begin{array}{l}\text { Budaya sekitar objek wisata yang } \\
\text { bisa menerima keberadaan } \\
\text { wisatawan }\end{array}$ & $\begin{array}{l}\text { Jalan yang bebas dari hewan ternak yang } \\
\text { berkeliaran di jalan }\end{array}$ \\
\hline & $\begin{array}{l}\text { Masyarakat mau membaur dengan } \\
\text { wisatawan }\end{array}$ & $\begin{array}{l}\text { Adanya pungutan yang memberatkan } \\
\text { wisatawan }\end{array}$ \\
\hline & $\begin{array}{l}\text { Masyarakat sangat antusias dengan } \\
\text { wiasatawan }\end{array}$ & $\begin{array}{l}\text { Kurangnya fasilitas ruangan ganti di objek } \\
\text { wisata }\end{array}$ \\
\hline & $\begin{array}{l}\text { Kerja sama antara masyarakat dan } \\
\text { wisatawan dalam hal ekonomi }\end{array}$ & $\begin{array}{l}\text { Tidak adanya fasilitas pendukung bagi } \\
\text { kegiatan wisatawan }\end{array}$ \\
\hline & $\begin{array}{l}\text { Adanya sarana untuk wisatawan } \\
\text { beristirahat }\end{array}$ & $\begin{array}{l}\text { Tidak adanya fasilitas mempermudah } \\
\text { transaksi keuangan wisatawan }\end{array}$ \\
\hline & $\begin{array}{l}\text { Adanya fasilitas untuk } \\
\text { mengeksplorasi objek wisata }\end{array}$ & $\begin{array}{l}\text { Prospek wisata yang tidak bisa lebih } \\
\text { berkembang }\end{array}$ \\
\hline & $\begin{array}{l}\text { Kondisi alam yang aman dan } \\
\text { nyaman }\end{array}$ & $\begin{array}{l}\text { Tidak adanya potensi ekonomi yang } \\
\text { memadai di lokasi wisata }\end{array}$ \\
\hline & & $\begin{array}{l}\text { Tidak bebas dari cuaca ekstrim terutama } \\
\text { cuaca di pingggir pantai }\end{array}$ \\
\hline & & $\begin{array}{l}\text { Wisata kurang aman dari hewan lauttivate } \\
\text { berbahaya }\end{array}$ \\
\hline Peluang (Opportunities) & so & wo \\
\hline Setiap ada hal unik baru senantiasa dipromosikan & \multirow{8}{*}{$\begin{array}{l}\text { 1. Mengembangkan aksesibilitas } \\
\text { yang baik dan nyaman bagi } \\
\text { wisatawan } \\
\text { 2. Membuat ivent dan pagelaran } \\
\text { budaya secara berkelanjutan }\end{array}$} & \multirow{8}{*}{$\begin{array}{l}\text { 1. Implementasi sapta pesona untuk } \\
\text { wisata pantai Botutonuo } \\
\text { 2. Membuat city Branding Pantai } \\
\text { Botutonuo } \\
\text { 3. Capacity Building bagi masyarakat } \\
\text { sekitar dalam hal ekonomi kretaif } \\
\text { berbasis masyarakat dan pariwisata } \\
\text { 4. Master plan wisata dan } \\
\text { pembangunan berkelanjutan } \\
\text { 5. Peran kelembagaan pariwisata yang } \\
\text { harus dioptimalkan }\end{array}$} \\
\hline $\begin{array}{l}\text { Stigma positif dari objek wisata menarik minat } \\
\text { masyarakat luas }\end{array}$ & & \\
\hline $\begin{array}{l}\text { Masyarakat sekitar memerlukan wisatawan untuk } \\
\text { peningkatan ekonomi }\end{array}$ & & \\
\hline $\begin{array}{l}\text { Masyarakat menjadi perpanjangan tangan } \\
\text { pemerintah daerah }\end{array}$ & & \\
\hline $\begin{array}{l}\text { Masyarakat turut andil dalam mencegah } \\
\text { keselamatan wisatawan }\end{array}$ & & \\
\hline Adanya komitmen program pengembangan wisata & & \\
\hline $\begin{array}{l}\text { Pemerintah melakukan acara atau ivent di lokasi } \\
\text { wisata }\end{array}$ & & \\
\hline $\begin{array}{l}\text { Sosialisasi kepariwisataan dan tindak lanjut modal } \\
\text { usaha ke masyarakat }\end{array}$ & & \\
\hline Ancaman (Threats) & ST & WT \\
\hline Adanya promosi oleh influencer wisata Gorontalo & \multirow{7}{*}{$\begin{array}{l}\text { 1. Membuat regulasi untuk } \\
\text { keberlanjutan wisata } \\
\text { 2. Melakukan promosi wisata } \\
\text { secara berkelanjutan }\end{array}$} & \multirow{7}{*}{$\begin{array}{l}\text { 1. Pembuatan spot wisata baru yang } \\
\text { bukan hanya bertema laut seperti } \\
\text { spot foto di gunung dan lainnya } \\
\text { 2. Penyediaan fasilitas dan berbagai } \\
\text { sarana prasarana yang menarik }\end{array}$} \\
\hline Promosi oleh LSM pecinta wisata & & \\
\hline $\begin{array}{l}\text { Adanya kerja sama dalam promosi wisata dari } \\
\text { semua pihak }\end{array}$ & & \\
\hline Masyarakat merasa memiliki objek wisata & & \\
\hline Masyarakat sekitar tidak melakukan pungli & & \\
\hline Adanya dukungan anggaran dari pemerintah & & \\
\hline $\begin{array}{l}\text { Melakukan kerja sama dengan kementerian } \\
\text { pariwisata }\end{array}$ & & \\
\hline
\end{tabular}




\section{Diagram Analisis SWOT Strategi pengembangan pariwisata dan ekonomi masyarakat Di Pantai Botutonuo Kabupaten Bone Bolango}

Maksud utama penerapan pendekatan ini adalah untuk mengidentifikasikan satu dari empat pola yang bersifat khas dalam keselarasan situasi internal dan eksternal yang dihadapi oleh Pantai Botutonuo Kabupaten Bone Bolango. Dari hasil tabel pengujian sebelumnya ditemukan bahwa:

1. Total skor untuk faktor (S) sebesar: 1,3032

2. Total skor untuk faktor (W) sebesar: 1,4265

3. Total skor untuk faktor $(\mathrm{O})$ sebesar: 1,5034

4. Total skor untuk faktor (T) sebesar: 1,2457

Berdasarkan hal tersebut maka dapat disusun titik koordinat dari digram SWOT berikut ini:

Tabel Koordinat Analisis Eksternal dan Internal Strategi pengembangan pariwisata dan ekonomi masyarakat

\begin{tabular}{|c|c|c|c|}
\hline No & & Uraian & Skor \\
\hline \multirow{4}{*}{1} & \multicolumn{2}{|c|}{ Faktor Internal } & \\
\hline & a. & Kekuatan & 1.3032 \\
\hline & b. & Kelemahan & 1.4265 \\
\hline & \multicolumn{2}{|r|}{ Selisih } & -0.1233 \\
\hline \multirow{4}{*}{2} & \multicolumn{2}{|c|}{ Faktor Eksternal } & \\
\hline & a. & Peluang & 1.5034 \\
\hline & b. & Ancaman & 1.2457 \\
\hline & \multicolumn{2}{|r|}{ Selisih } & 0.2577 \\
\hline \multicolumn{3}{|c|}{ Titik Koordinat $\underline{\underline{X}, \underline{Y}}$} & $(-0,1233.0,2577)$ \\
\hline
\end{tabular}

Sumber Pengolahan Data Primer, 2020

Keempat pola tersebut biasanya digambarkan dalam empat sel seperti pada Gambar berikut ini:

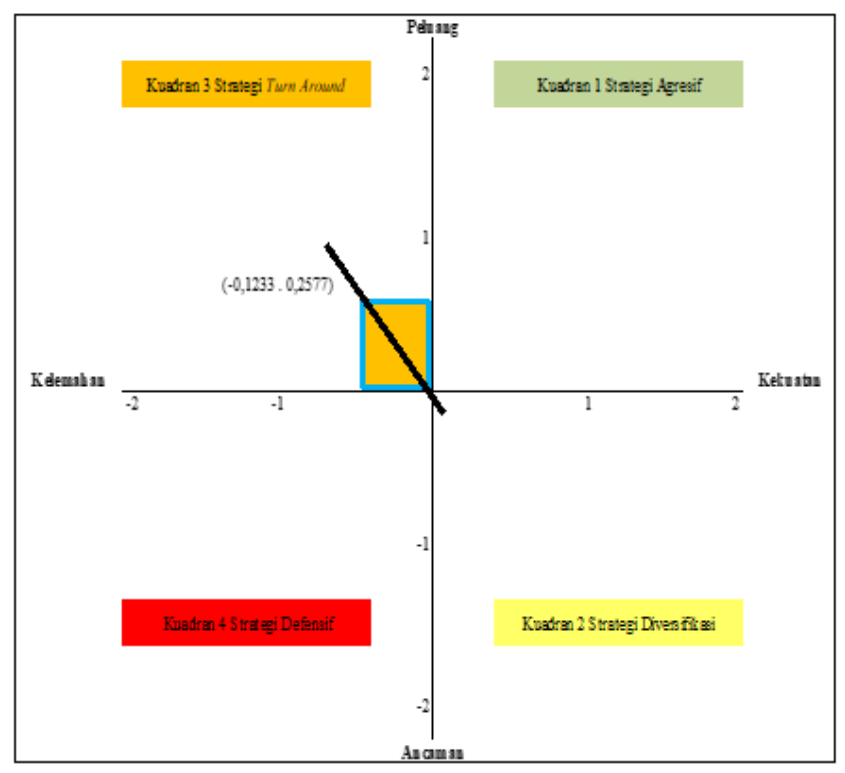

Gambar. Diagram Analisis SWOT Kualitas Pelayanan Pantai Botutonuo Kabupaten Bone Bolango

Terkait dengan kasus posisi strategi pengembangan pariwisata dan ekonomi masyarakat di Pantai Botutonuo Kabupaten Bone Bolango saat ini berada pada kuadran 3 yakni startegi Turn Around. Strategi ini menekankan bahwa pentingnya komitmen pemerintah mengenai fokus pembangunan pariwisata daerah yang dapat dilakukan melalui upaya (1) implementasi sapta pesona untuk wisata pantai Botutonuo, (2) membuat city branding Pantai Botutonuo, (2) Capacity Building bagi masyarakat sekitar dalam hal ekonomi kretaif berbasis masyarakat dan pariwisata, (4) master plan wisata dan pembangunan berkelanjutan, mengoptimalkan peran kelembagaan pariwisata dalam memenuhi target pendapatan asli daerah Kabupaten dan peningkatan ekonomi masyarakat termasuk dalam mengurangi kemiskinan dan meningkatkan 
penyerapan tenaga kerja masyarakat di Desa Botutonuo. Strategi ini harus lebih didorong pengembangannya secara lebih kuat dan diarahkan secara tepat untuk meningkatkan keunggulan branding dan keunggulan daya saing wisata di Kabupaten Bone Bolango.

\section{Pembahasan}

Sukses atau keberhasilan jangka panjang pariwisata sangat tergantung pada tingkat penerimaan dan dukungan dari komunitas lokal. Karena itu, untuk memastikan bahwa pengembangan pariwisata di suatu tempat dapat dikelola dengan baik dan berkelanjutan, maka hal mendasar yang harus diwujudkan untuk mendukung tujuan tersebut adalah bagaimana memfasilitasi keterlibatan yang luas dari komunitas lokal dalam proses pengembangan dan memaksimalkan nilai manfaat sosial dan ekonomi dari kegiatan pariwisata.

Sehingga pariwisata merupakan perjalanan untuk memenuhi hasrat dan keingintahuan akan kepentingan yang berhubungan dengan kesenangan. Objek wisata adalah segala sesuatu yang ada di daerah tujuan wisata yang merupakan daya tarik agar orang-orang mau berkunjung ke tempat tersebut.

Hasil penelitian menunjukan bahwa posisi strategi pengembangan pariwisata dan ekonomi masyarakat di Pantai Botutonuo Kabupaten Bone Bolango saat ini berada pada kuadran 3 yakni startegi Turn Around. Strategi ini menekankan bahwa pentingnya komitmen pemerintah mengenai fokus pembangunan pariwisata daerah yang dapat dilakukan melalui upaya (1) implementasi sapta pesona untuk wisata pantai Botutonuo, (2) membuat city branding Pantai Botutonuo, (2) Capacity Building bagi masyarakat sekitar dalam hal ekonomi kretaif berbasis masyarakat dan pariwisata, (4) master plan wisata dan pembangunan berkelanjutan, (5) mengoptimalkan peran kelembagaan pariwisata dalam memenuhi target pendapatan asli daerah Kabupaten dan peningkatan ekonomi masyarakat termasuk dalam mengurangi kemiskinan dan meningkatkan penyerapan tenaga kerja masyarakat di Desa Botutonuo. Strategi ini harus lebih didorong pengembangannya secara lebih kuat dan diarahkan secara tepat untuk meningkatkan keunggulan banding dan keunggulan saing wisata di Kabupaten Bone Bolango.

Sapta Pesona adalah untuk meningkatkan kesadaran, rasa tanggung jawab segenap lapisan masyarakat, baik pemerintah, swasta maupun masyarakat luas untuk mampu bertindak dan mewujudkannya dalam kehidupan sehari-hari. Pelaksanaan sapta pesona merupakan inti dari program pemerintah dalam meningkatkan sadar wisata masyarakat dan merupakan dalam meningkatkan sadar wisata masyarakat dan merupakan syarat mutlak dalam usaha pembangunan pariwisata kearah yang lebih mantap oleh karena itu sapta pesona dijadikan program nasional yang bertujuan meningkatkan kesadaran serta tanggung jawab segenap lapisan pemerintah, swasta, dan masyarakat. Kehadirannya memang sangat begitu terasa penting dan sudah saatnya dibutuhkan, bukan hanya sebagai kebutuhan pokok wisatawan, tetapi juga sebagai tolak ukur dalam meningkatkan kualitas pariwisata. Pelaksananaan sapta pesona merupakan inti dari program dalam 
meningkatkan sadar wisata masyarakat dan merupakan syarat dalam usaha pengembangan pariwisata kearah yang lebih baik. Sapta pesona sebagai pedoman nasional yang yang memiliki tujuan. Adapun tujuan sapta pesona yang ditetapkan oleh Dirjen Pariwisata dalam Bakaruddin (2009) ada 7 (tujuh) pesona yaitu kemananan, ketertiban, kebersihan, kesejukan, keindahan, keramah-tamah dan kenangan. Apabila semua aspek itu diperoleh oleh wisatawan maka akan meningkatkan minat berkunjung kembali pada wisata tersebut.

Penguatan kelembagaan untuk wisata sangatlah penting terutama suatu wisata yang dikelola secara kelembagaan oleh BUMDes atau lembaga lainnya di Kabupaten Bone Bolango. Hal ini sebagaimana menurut Meiske (2014), upaya peningkatan daya guna dan hasil guna bantuan pembangunan desa telah mendorong bahkan menggerakan swadaya gotong royong serta menumbuhkan otoaktivitas masyarakat dalam pembangunan desa, bantuan ini sangat penting dan bermanfaat untuk pembangunan, ternyata rangsangan riil telah membawa dampak positif bagi masyarakat desa, terutama dalam hal memobilisasi potensi desa seperti dana, tenaga, dan pikiran yang dimilikii masyarakat. BUMDes sebagai lembaga sosial berpihak kepada kepentingan masyarakat melalui kontribusinya dalam penyediaan pelayanan sosial, sedangkan sebagai lembaga komersial bertujuan mencari keuntungan untuk meningkatkan pendapatan dan ekonomi masyarakat desa. Hal yang sama juga diungkapkan oleh bahwa Suwondo (2016), bumdes ini diharapkan juga mampu menstimulasi dan menggerakkan roda perekonomian di pedesaan, aset ekonomii yang ada di desa harus dikelola sepenuhnya oleh masyarakat desa, substansi dan filosofi BUMDes harus dijiwai dengan semangat kebersamaan dan upaya memperkuat aspek ekonomi kelembagaannya.

Melalui hasil ini maka pemerintah harus mempromosikan destinasi secara bertanggung jawab (responsible) yang tujuannya adalah memaksimalkan benefit bagi masyarakat lokal dan berkelanjutan. Dalam hal ini pemasaran suatu destinasi tidak hanya diorientasikan pada meraih kunjungan yang sebesar-besarnya tetapi juga memperhitungkan daya dukung lingkungan dan sumberdaya yang tersedia. Kemudian perlu adanya kerja sama dengan para investor atau perusahaan yang berdiri di Kabupaten Bone Bolango agar CSR dari perusahaan diarahkan dalam upaya pembangunan wisata dan pengembangan ekonomi bagi masyarakat di sekitar wisata di Kabupaten Bone Bolango. Dengan cara ini maka seluruh elemen pelaku ekonomi akan memberikan kontribusi nyata dalam pengembangan wisata.

Hasil ini sesuai pula dengan penelitian dari Asnawi Manaf (2013) bahwa Pelaku utama didalam kegiatan pariwisata terutama wisata budaya dan adat istiadat ini adalah masyarakat pelaku wisata. Dana PNPM Mandiri Pariwisata diberikan untuk memfasilitasi masyarakat pelaku wisata atau embrio aktivitas masyarakat yang menjadi daya tarik wisata. Sehingga masyarakat pelaku wisata ini secara mandiri, merencanakan, mengalokasikan dan mengelola dana yang mereka dapat dan menggunakannya sebagai alat untuk 
mensupport dalam pekerjaan menjadi pelaku wisata. Pemerataan pemanfaatan Dana PNPM Mandiri Pariwisata di Desa ini cukup terbilang merata dan menyentuh langsung masyarakat pelaku wisata dan pokdarwis sebagai komunitas yang membina saja. Selain itu realisasi dana PNPM Mandiri Pariwisata ini juga sangat bagus, karena realisasi berdasarkan embrio (kegiatan masyarakat yang sudah berjalan dan menjadi daya tarik wisata). Sehingga menyebabkan desa ini menjadi lebih layak jual, kreatif dan menjadi destinasi wisatawan seperti saat ini.

\section{Penutup}

\section{Simpulan}

Berdasarkan hasil penelitian dan pembahasan pada bab sebelumnya maka dapat ditarik simpulan sebagai berikut:

1. Faktor Penghambat \& Pendorong Pariwisata Pantai Botutonuo di Kabupaten Bone Bolango. Faktor Penghambat yang meliputi: a). Minimnya moda transportasi pada kawasan wisata, b). Peran lembaga pengelolah pariwisata, c). Pemanfaatan media promosi (ketidak optimalan pemanfaatan media dalam promosi wisata, d). Sampah berserakan yang belum terkontrol dan menyebabkan daya tarik wisatawan menurun, e). Ketidak tersediaan fasilitas kebencanaan pesisir dan tindakan mitigasi bencana pesisir pantai. Faktor Pendorong yang meliputi: a). Aksebilitas menuju lokasi wisata, b). Pelayanan baik pelaku uasaha/masyarakat terhadap wisatawan, c). Ketersanaan sarana dan prasarana pariwisata, d). Peran masyarakat yang aktif untuk mendukung perkembangan pariwisata, e). Adanya dukungan anggaran dari pemerintah.

2. Strategi pemetaan potensi pariwisata pantai Botutonuo di Kabupaten Bone Bolango dapat dilakukan melalui pemetaan strategi alternative melalui strategi S-O (Strength-Opportunities), strategi W-O (WeaknessesOpportunitties), strategi S-T (StrengthThreatsh), dan strategi W-T (Weaknesses-Threatsh) yang meliputi: a). Mengembangkan aksesibilitas yang baik dan nyaman bagi wisatawan; b). Membuat ivent dan pagelaran budaya secara berkelanjutan; 3). Implementasi sapta pesona untuk wisata pantai Botutonuo; 4). Membuat regulasi untuk keberlanjutan wisata; 5). Melakukan promosi wisata secara berkelanjutan; 6). Penyediaan fasilitas dan berbagai sarana prasarana yang menarik

3. Desain pengembangan potensi pariwisata pantai Botutonuo dapat dilakukan melalui startegi Turn Around. Strategi ini menekankan bahwa pentingnya komitmen pemerintah mengenai fokus pembangunan pariwisata daerah yang dapat dilakukan melalui upaya upaya (1) implementasi sapta pesona untuk wisata pantai Botutonuo, (2) membuat city branding Pantai Botutonuo, (2) Capacity Building bagi masyarakat sekitar dalam hal ekonomi kretaif berbasis masyarakat dan pariwisata, (4) master plan wisata dan pembangunan berkelanjutan, (5) mengoptimalkan peran kelembagaan pariwisata. 


\section{Saran}

Berdasarkan hasil pada simpulan, maka yang menjadi saran dalam penelitian ini yaitu:

1. Pemerintah perlu menawarkan konsep keberlanjutan dan pemberdayaan masyarakat yang berbasis budaya dan ekonomi kreatif dengan mengacu pada upaya-upaya mempromosikan destinasi secara bertanggung jawab (responsible) yang tujuannya adalah memaksimalkan benefit bagi masyarakat lokal dan berkelanjutan. Dalam hal ini pemasaran suatu destinasi tidak hanya diorientasikan pada meraih kunjungan yang sebesarbesarnya tetapi juga memperhitungkan daya dukung lingkungan dan sumberdaya yang tersedia.

2. Perlu adanya kerja sama dengan para investor atau perusahaan yang berdiri di Kabupaten Bone Bolango agar CSR dari perusahaan diarahkan dalam upaya pembangunan wisata dan pengembangan ekonomi bagi masyarakat di sekitar wisata di Kabupaten Bone Bolango. Dengan cara ini maka seluruh elemen pelaku ekonomi akan memberikan kontribusi nyata dalam pengembangan wisata.

3. Pemerintah dan masyarakat harus lebih optimal dalam pemanfaatan teknologi informasi terutama media sosial dalam rnagka untuk mempromosikan wisata dengan berbagai kelebihan alat promosi yang ada dalam media sosial. Kemudian khusus bagi masyarakat perlu menjaga dan meningkatkan komitmen dalam pengembangan wisata dan meningkatkan kemauan untuk lebih kreatif dalam membuat produk atau jasa yang mendatangkan manfaat ekonomi masyarakat dan meningkatkan pendapatan perkapita masyarakat di sekitar objek wisata pantai Botutonuo Kabupaten Bone Bolango.

\section{Daftar Pustaka}

Asmarani, Asri Dwi. 2010. Strategi Kebijakan Pembangunan Daerah Kabupaten Klaten: Pendekatan Analisis SWOT dan AHP. Tesis: Universitas Indonesia

Anggraini, Nilam. 2009. Peranan sektor Pariwisata terhadap Perekonomian Indonesia suatu pendekatan sistem neraca sosial ekonomi (SNSE)

Daryanto A, Hafizrianda Y. 2010. Analisis Input-Output \& Sosial Accounting Matrix Untuk Pembangunan Ekonomi Daerah. Okttariani A, Syarifah SS, editor. Bogor: IPB Press.

David, Fred R. \& David, Forest. R. 2016. Manajement strategik: Suatu Pendekatan Keunggulan Bersaing. Jakarta, Penerbit Salemba Empat

Elfianita, E. (2016). Pengembangan Pariwisata Berbasis Community Based Tourism (CBT) Di Desa Wisata Limbasari Kecamatan Bobotsari, Kabupaten Purbalingga, Jurnal Elektronik Mahasiswa Pend. Luar sekolah-S1, 5(3)

Fairuza, Mia. 2015. Kaloborasi Antar Stakeholder Dalam Pembangunan Inklusif Pada Sektor Pariwisata (Studi Kasus Wisata Pulau Merah Di Kabupaten Banyuangi)

Hapsa. 2016. Peran Dinas Kebudayaan

Pariwisata Dan Kominfo Kota Samarinda Dalam Pengembangan Kawasan Wisata Di Kota Samarinda. 
Harahap,Nudin Saifullah. 2013. Strategi Pengembangan Wisata Mangrove di "Blok Bedul" Taman Nasional AIAS Purwo Kabupaten Banyuangi Jawa Timur.

Hasbi, Andi. 2018. Pembangunan Pariwisata Budaya (studi kasus di tanah toraja)

Ismayanti. 2010. Pengantar Pariwisata. Jakarta: Penerbit Grasindo

Manaf, Asnawati dan Putri, jakti Prabawati Hemas. 2013. Faktorfaktor keberhasilan pengembangan desa wisata di dataran tinggi Dieng Maku, D.,\& Pariono, A. (2018) Peran Kepala Desa Dalam Menyelesaikan Konflik Di Obyek Wisata Pantai Botutonuo Kecamatan Kabila Bone, Kabupaten Bone Bolango Vol.5 No.2 78-86

Mankiw. G 2007. Makroekonomi Edisi Keenam.Liza F, Nurmawan penerjemah.Barnadi D, Hardani W, Saat S, editor.Jakarta: Erlangga.

Marimin, 2004, Pengambilan Keputusan Kriteria Majemuk, Teknik Dan Aplikasi.

Ni'mah, Izzatun. 2016. Public-Private Partnership untuk Meningkatkan Pertumbuhan Ekonomi Sektor Pariwisata di Wilayah Kedungsepur. Economics Development Analysis Journal. Vol.5 No.4, 410-425

Perdamen, Fandi. 2020. Strategi Peningkatan Daya Saing UMK. Tesis: Universitas Lampung.

Rangkuti,Freddy. Personal SWOT analysis.gramedia pustaka utama. 2015

Republik Indonesia. 2011. Peraturan Pemerintah Pemerintah Indonesia Nomor 50 Tahun 2011 Tentang Rencana
Induk Pembangunan Kepariwisataan Nasional Tahun 2010-2025. Sekretariat Negara. Jakarta.

Sadoulet E, A de Janvry. 1995 . Quantitative Development Policy Analysis.Baltimore. The Johns Hopkins University Press Press

Surwiyanta, A. 2003. Dampak pengembangan pariwisata terhadap kehidupan sosial budaya dan ekonomi. Media Wisata, 2(1)

Suwartoro, Gamal. 2004. Dasar-dasar Pariwisata. Yogjakarta: Penerbit Andi.

Teguh F dan Evenzora R. 2013. Ekowisata dan Pembangunan Pariwisata Berkelanjutan di Indonesia, Potensi, Pembelajaran, dan Kesuksesan. Jakarta. Kementerian Pariwisata dan Ekonomi Kreatif.

Tohjiwa, A. D., Soetomo, S., Sjahbana, J. A., \& Purwanto, E. (2010). Kota Bogor dalam Tarik Menarik Kekuatan Lokal dan Regional. In Seminar Nasional Riset Arsitektur dan Perencaan (SERAP) 1. Universits Gadjah Mada.

Tumbel, Tinneke Meiske. "Analisis Bantuan Desa Terhadap Pelaksanaan Pembangunan Desa (Studi Kasus Pada Kecamatan Tareran Kabupaten Minahasa Selatan)." Jurnal LPPM Bidang EkoSosBudKum 1.2 (2014): 1-12Yoeti Oka A, 2006. Tours and Travel Marketing. Jakarta. Penerbit Pradnya Paramita. 